\title{
Using GIS and Remote Sensing in Assessment of Water Scarcity in Nakuru County, Kenya
}

\author{
Catherine Changwony, Arthur W. Sichangi, Moses Murimi Ngigi \\ Institute of Geomatics, GIS and Remote Sensing (IGGReS), Dedan Kimathi University of Technology, Nyeri, Kenya \\ Email: jeptim2006@yahoo.com, arthursichangi@yahoo.com,murimi99@gmail.com
}

How to cite this paper: Changwony, C., Sichangi, A.W. and Ngigi, M.M. (2017) Using GIS and Remote Sensing in Assessment of Water Scarcity in Nakuru County, Kenya. Advances in Remote Sensing, 6, 88102.

https://doi.org/10.4236/ars.2017.61007

Received: January 27, 2017

Accepted: March 7, 2017

Published: March 10, 2017

Copyright $\odot 2017$ by authors and Scientific Research Publishing Inc. This work is licensed under the Creative Commons Attribution International License (CC BY 4.0).

http://creativecommons.org/licenses/by/4.0/

\section{Open Access}

\begin{abstract}
Water is at the core of sustainable development and is critical for socio-economic development, healthy ecosystems and for human survival. This research study has been carried out in Nakuru County, a tropical region in the Rift Valley of Kenya, bounded between latitude $0.28^{\circ} \mathrm{N}$ and $1.16^{\circ} \mathrm{S}$, and longitude $36.27^{\circ} \mathrm{E}$ and $36.55^{\circ} \mathrm{E}$. The objective of the study has been to use GIS and remote sensing in assessment of water scarcity using Land use Land cover area changes, standard precipitation index and crop yields. Landsat satellite images for the year 1985, 1995, 2005 and 2015 were used. Classification was done using maximum likelihood algorithm while classification accuracy assessment entailed the use of confusion matrix method and ground truth data. Post classification change detection results gave percentage cropland areas as $21 \%$ in 1985, 29\% in 1995, 53\% in 2005 and also 53\% in 2015. Eleven (11) ground rainfall stations and TRMM satellite rainfall data from 1985 to 2015 has been used to show meteorological drought. Validation of rainfall data done using correlation coefficient $\left(\mathrm{R}^{2}\right)$ and root mean square (RMS) methods showed that ground rainfall data and TRMM data correlate. Modelling of 3 months SPI for each of the three seasons (MAM, JJA and OND) has been done using interpolation distance weighted method (IDW). 3 months SPI time scales curves gave October 1987, May 1993, and July 2004 as water scarce and dry seasons and were categorized as either Normal, moderately dry, severely dry and extremely dry. Crop yield trends curves showed crop yield decrease in this identified water scarce and dry years. Conclusion reached is that crop yields is not dependent on size of land ploughed only but mostly on rainfall quantities. Therefore, the findings of this research can be used as drought monitoring tools.
\end{abstract}

\section{Keywords}

Land Use Land Cover (LULC), Meteorological Drought, Standard Precipitation Index (SPI), Water Scarcity 


\section{Introduction}

Water is at the core of sustainable development and is critical for socio-economic development, healthy ecosystems and for human survival itself [1]. Water use has been growing at more than twice the rate of population increase in the last century, and, although there is no global water scarcity as such, an increasing number of regions are chronically short of water [2]. On the other hand, agriculture is the largest consumer of water in Africa and Asia and plays an essential role in economic development and poverty reduction in these regions [3].

Water scarcity caused fully or in part by human activities and reflects conditions with long-term imbalances between available water resources and demands [4], can lead to common effects like reduced production of crops, higher costs of commodities and political stresses [5]. The water scarcity is being further compounded by droughts which affect both surface water and groundwater resources and can lead to reduced water supply, deteriorated water quality, crop failure, and disturbed riparian habitats [6]. Hence, this research study has been carried because understanding drought and modeling its components have drawn attention of ecologists, hydrologists, meteorologists, and agricultural scientists [7]. Therefore, a simple but robust definition of the marginal value of a unit of water, highlighting key aspects of water scarcity and illustrating its many biophysical and socioeconomic determinants is required [8].

Furthermore, uncertain effects of future climate change on water scarcity can add to the need for clarity on the concept of water scarcity since water scarcity may also limit food production and supply, putting pressure on food prices and increasing countries' dependence on food imports [9]. Because of these facts, this research study in Nakuru County, Kenya has been carried out in order to investigate if there is a reason behind decrease or increase of crop yield during different rainfall seasons. A study had been previously carried to show the relationship between economic efficiency and farm size [10] but none has been carried out to show that rainfall quantities is the reason to decrease in crop yields and not the farm size.

\section{Methodology}

\subsection{Description of the Study Area}

Nakuru county is located in the great rift valley and it is bounded between latitude $0.28 \mathrm{~N}$ and $1.16 \mathrm{~S}$ and longitude $36.27 \mathrm{E}$ and $36.55 \mathrm{E}$. It is reach in diversity since it has tourists attraction sites for local and international tourists because of the beautiful slopes of the great rift valley, menengai crator, mau complex and several lakes including Lake Nakuru and Lake elementaita. It also has sub counties including Kuresoi, Naivasha, and Molo, Nakuru town, Rongai and subukia amongst others. Figure 1 shows the location of the study area

\subsection{Objectives of Study}

a) To characterize various land cover and land uses within Nakuru County and to analyze if land occupied by crops affects the crop yield.

b) To model water scarce and dry seasons in the study area using standard pre- 


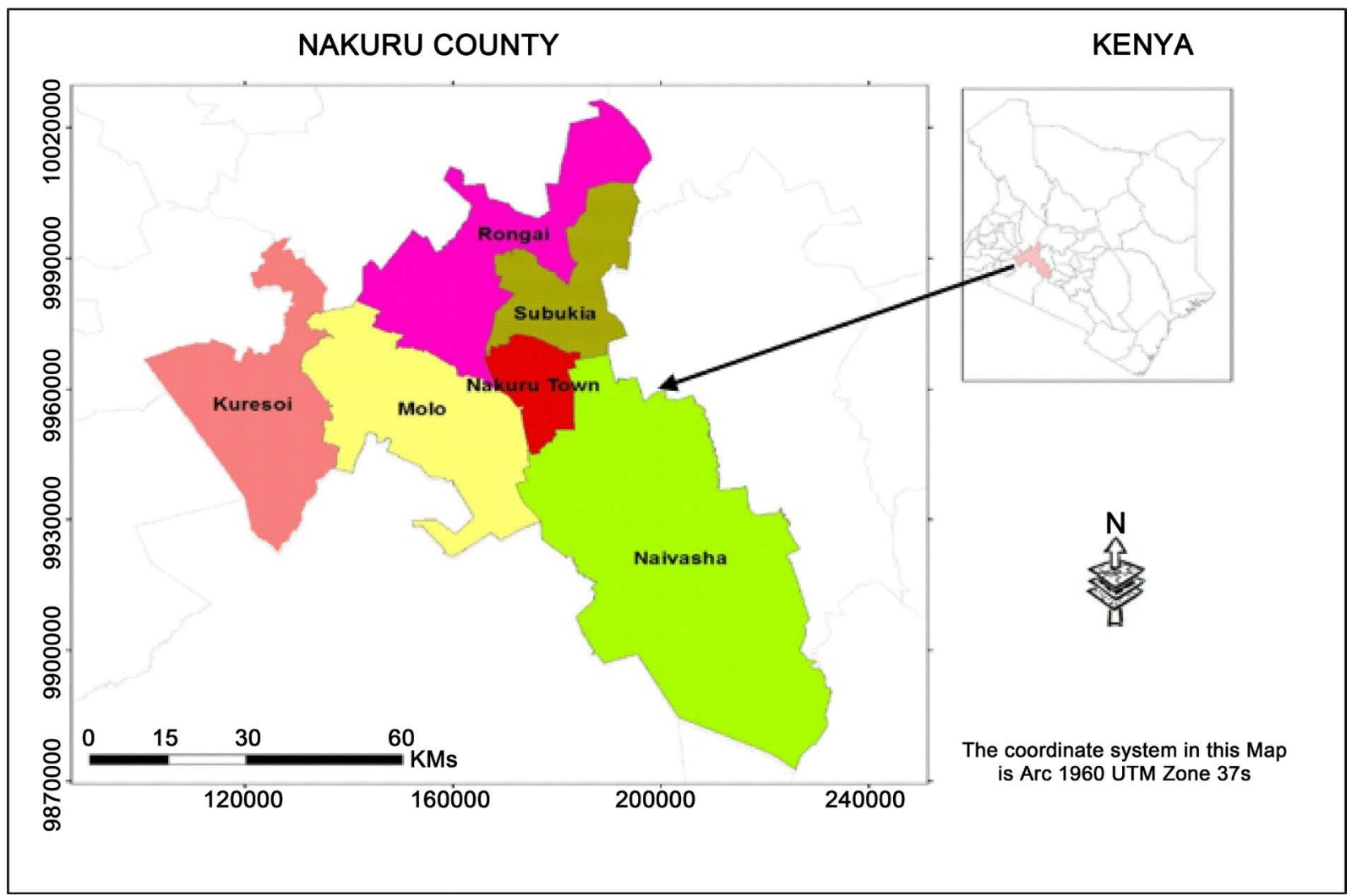

Figure 1. Study area.

cipitation index (SPI) and according climatic seasons (MAM, JJA and OND).

c) To show the relationship between standard precipitation index (SPI) and crop yields trends.

\subsection{Datasets, Their Sources and the Flow Diagram of Methodology}

This project involved three types of data sets which includes; Landsat TM satellite imageries, rainfall data from both ground and tropical rainfall monitoring mission (TRMM) and crop yield data. Landsat TM images were downloaded from USG through Regional Centre for monitoring and resource development (RCMRD), ground stations rainfall data were collected from Kenya meteorological station while TRMM rainfall satellite data was acquired from precipitation processing system (PPS) and a code for downloading the 3B43 TRMM multi satellite precipitation files was written in python 2.7 program. On the other hand, crop yield data were collected from both Ministry of Livestock and fisheries office in Nairobi city Headquarters and the Nakuru County office, department of agriculture. The software used was; Erdas imagine 2014, Arc Map 10.1 Python 2.7 python and Microsoft excel 2013. Table 1 shows the data type, their sources and the software used.

In order to achieve water scarcity assessment the methodology employed involved integration of Land sat TM images, meteorological rainfall data and socio economic crop yields data. Land sat TM images were prepared, processed and classified using supervised classification method. Classification accuracy assess- 
Table 1. Data types, their sources and software used.

\begin{tabular}{|c|c|c|}
\hline Data type & source & Software used \\
\hline $\begin{array}{c}\text { Landsat TM } \\
\text { satellite imagery }\end{array}$ & $\begin{array}{l}\text { Downloaded from USG through Regional } \\
\text { centre for monitoring of resources and } \\
\text { Development (RCMRD) }\end{array}$ & ERDAS imagine 2014 \\
\hline Rainfall data & $\begin{array}{l}\text { Kenya meteorological department } \\
\text { Headquarters Nairobi and Trophical Rainfall } \\
\text { Monitoring Mission (TRMM) through } \\
\text { (PPS-Precipitation processing system) }\end{array}$ & $\begin{array}{l}\text { Microsoft excel 2013, } \\
\text { python } 2.7 \text { phthon, SPI } \\
\text { program, Arcmap } 10.1 \text { and } \\
\text { Microsoft excel } 2013\end{array}$ \\
\hline $\begin{array}{l}\text { Crop yield data } \\
\text { (90 kg bag/Ha) }\end{array}$ & $\begin{array}{l}\text { Minstry of a Agriculture, livestock and } \\
\text { fisheries(Headquarters, Nairobi) and Nakuru } \\
\text { county office (department of Agriculture) }\end{array}$ & Microsoft excel 2013 \\
\hline
\end{tabular}

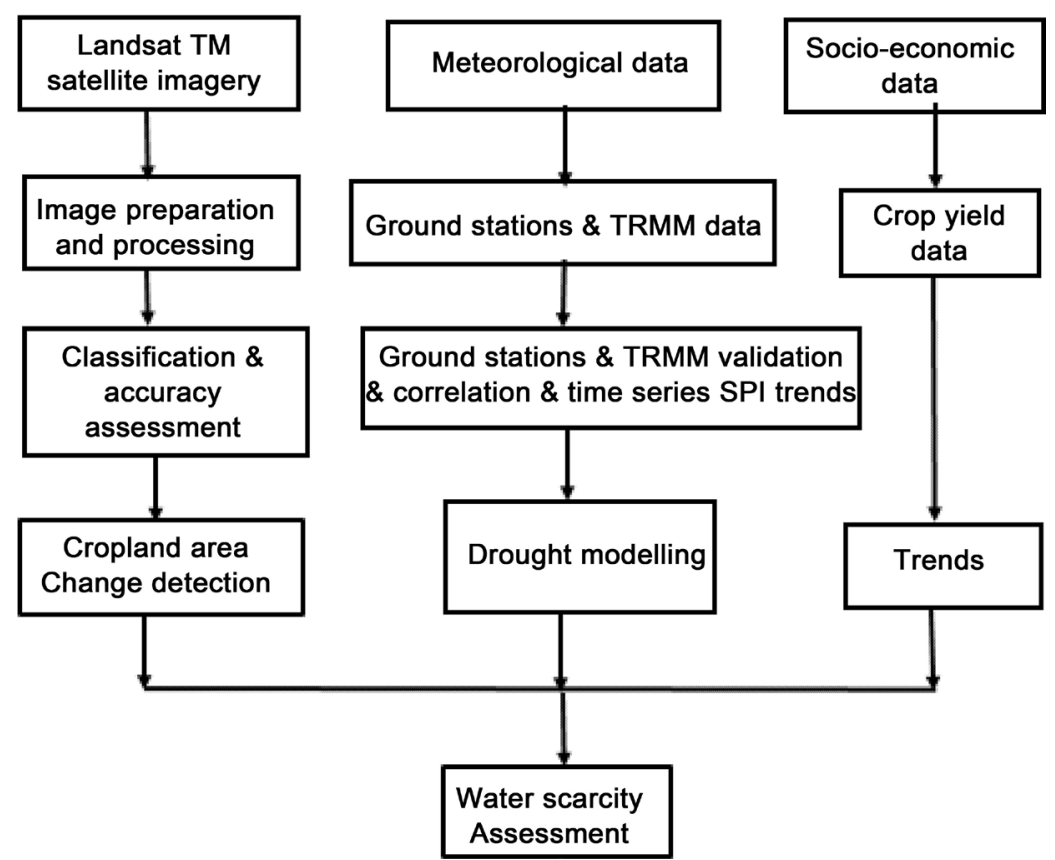

Figure 2. Flow diagram of methodology.

ment and area change detection was done. Classification accuracy was carried out using confusion matrix and ground truth data. Meteorological data was the ground rainfall data and the TRMM rainfall satellite data which was correlated and validated before SPI timescales curves ware drawn. From the SPI timescales curves for long term time series from 1985 to 2015, drought and water scarce years were identified and modeled using McKee et al., 1993 SPI categories. Crop yields trends curves were drawn so as to come with SPI models and be able to justify the existence of water scarcity and drought in the identified years. Figure 2 is the flow diagram of methodology.

\subsection{Data Processing and Analysis}

\subsubsection{Land Use Land Cover (LULC) Classification}

In order to get the areas covered by cropland, land use land cover (LULC) classi- 
fication was carried out. Four (4) Landsat images of 10 years interval each with 30 meters resolution were used. These images were for years 1985, 1995, 2005, and 2015, and they were in tiff format since they had already been corrected for radiometric and geometric distortions errors. The processing was done using both Erdas imagine software 2014 and Arcmap 10.1.

These processes were; layer stacking, Mosaicing, reprojection, subsettin/clipping, classification, accuracy assessment done (using confusion matrix and ground truth data) and area change detection. The Landsat images scenes covering the study area were 169/60,169/61,168/60 and 169/61. Five classes chosen were forestland, grassland, cropland, wetland and other land. The aim in this classification was basically to know the amount of land occupied by crops. Supervised method of classification was used and the classification algorithm was maximum likelihood classifier.

The results of classification were presented as percentage in piecharts through the use of Microsoft excel 2013 software.

\subsubsection{Validation and Correlation of Ground Station Rainfall Data with TRMM Rainfall Data}

Validation of the both ground station rainfall data and TRMM rainfall data sets was very vital in order to do accuracy assessment of the data. Therefore two stations with 30 years' time series rainfall data were used to validate with TRMM rainfall data. Validation was done starting from January 1998 to December 2015 since TRMM data started from 1998. Both Nakuru meteorological station (New) and Olkaria Geothermal ground stations had two sets of data overlapping for period 1998 to 2015. Ground station data was validated with TRMM rainfall data having horizontal resolution of 0.25 degrees by 0.25 degrees area coverage. Root mean square (RMS) and correlation coefficient $\left(\mathrm{R}^{2}\right)$ methods were used to do this error validation.

\subsubsection{SPI Trend Curves and Identifying of Water Scarce and Dry Years and Seasons}

Data from eleven (11) ground rainfall stations with which missing data had been filled using TRMM rainfall data were used. From each ground station data, SPI trend curves were plotted using Microsoft excel 2013 program. SPI program enabled the generation of SPI timescales for long term series. Each station had five (5) SPI trend curves representing 1 month SPI, 3 month SPI, 6 month, SPI 9 month SPI and 12 month SPI timescales respectively. IDW interpolation method was used to map the distribution of drought and water scarcity for the years identified to be having low and negative SPI values. McKee et al. 1993 SPI classes and categories were adopted whereby, -0.99 to -0.99 is Normal, -1.0 to1.49 is moderately dry, -1.5 to -1.99 is very dry and -2 and less is extremely dry. Table 2 is showing SPI categories by McKee et al., 1993.

\subsubsection{Crop Yields Trends}

Time series Crop yield were data collected for two crops; maize and wheat. These long series data from 1985 to 2015 were organized in Microsoft excel sheets and 
Table 2. SPI categories by McKee et al., 1993.

\begin{tabular}{cc}
\hline SPI Value & Class \\
$2.0+$ & Extremely wet \\
1.5 to 1.99 & Very wet \\
1.0 to 1.49 & Moderately wet \\
-0.99 to 0.99 & normal \\
-1.0 to 1.49 & Moderately dry \\
1.5 to -1.99 & Very dry \\
$-2.0+$ & Extremely dry \\
\hline
\end{tabular}

trend curves drawn. The crop yield was in $90 \mathrm{~kg}$ bags per hectare. Figure 13 shows the crop yields trends for both maize and wheat for the period 1985 to 2015.

\section{Results and Discussion}

\subsection{LULC Classification Results}

LULC classification results revealed that in the year 1985 land under cropland was $21 \%$, in the year 1995 it was 29\%, and also 53\% in both the year 2005 and 2015 as seen in the Figure 4. On the other hand, classification accuracy assessment done gave overall accuracy of $82.68 \%$ in the year $1985,84.5 \%$ in the year $1995,84.3 \%$ in the year 2005 and $84.78 \%$ in the year 2015 as illustrated in Tables 3(a)-(d).

Figure 3 shows classified images of 1985, 1995, 2005 and 2015.Five classes chosen were Forestland, grassland, cropland, wetland and other land.

\subsection{SPI Trends, Rainfall Data Validation, Correlation and Water Scarcity and Drought Modelling}

In this research, validation of two rainfall data sets was carried out for accuracy assessment purposes. Results revealed that there was noticeable correlation between ground rainfall data and the TRMM data for all rainfall stations .For example validation of data sets for Nakuru meteorological station (New) and Olkaria meteorological station gave correlation coefficient which was within allowable limit. Nakuru meteorological station (New) had correlation coefficient of 0.725 while that of Olkaria meteorological station was 0.7501 . This could be mainly because both ground rainfall data and TRMM have surface vertical resolution. TRMM occupies spatial extent of $25 \mathrm{~km}$ by $25 \mathrm{~km}$ while ground station has point accuracy but all experiences some linearity in terms of surface resolution. Likewise the root mean square (RMS) method showed some sort of lack correlation since Olkaria meteorological station had residual sum of squares (RSS) of $672,101.17$ and the root mean square error (RMSE) of 71.35, while Nakuru meteorological station had RSS of 296,167.85 and RMSE of 39.27. Figure 5 shows correlation and validation for TRMM and ground data for Olkaria meteorological station and Figure 6 shows correlation and validation for TRMM and ground data for Nakuru meteorological station (New). 
Table 3. Classification accuracy assessment for 1985, 1995, 2005 and 2015 respectively.

(a)

\begin{tabular}{|c|c|c|c|c|c|c|c|c|}
\hline \multirow{2}{*}{\multicolumn{2}{|c|}{1985}} & \multicolumn{4}{|c|}{ Ground Classes } & \multirow[b]{2}{*}{ Other land } & \multirow[b]{2}{*}{ Total } & \multirow[b]{2}{*}{ User Accuracy } \\
\hline & & Forestland & Grassland & Cropland & Wetland & & & \\
\hline \multirow{7}{*}{ Map Classes } & Forestland & 63 & 3 & 1 & 1 & 2 & 70 & $90.00 \%$ \\
\hline & Grassland & 1 & 47 & 3 & 1 & 4 & 56 & $83.93 \%$ \\
\hline & Cropland & 2 & 2 & 54 & 1 & 4 & 63 & $85.71 \%$ \\
\hline & Wetland & 1 & 3 & 2 & 19 & 1 & 26 & $73.08 \%$ \\
\hline & Other land & 3 & 4 & 3 & 2 & 27 & 39 & $69.23 \%$ \\
\hline & Total & 70 & 59 & 63 & 24 & 38 & 254 & \\
\hline & Producer accuracy & $90.00 \%$ & $79.66 \%$ & $85.71 \%$ & $79.17 \%$ & $71.05 \%$ & & \\
\hline Overall accuracy & $82.68 \%$ & & & & & & & \\
\hline
\end{tabular}

(b)

\begin{tabular}{|c|c|c|c|c|c|c|c|c|}
\hline \multirow{2}{*}{\multicolumn{2}{|c|}{1995}} & \multicolumn{4}{|c|}{ Ground Classes } & \multirow[b]{2}{*}{ Other land } & \multirow[b]{2}{*}{ Total } & \multirow[b]{2}{*}{ User Accuracy } \\
\hline & & Forestland & Grassland & Cropland & Wetland & & & \\
\hline & Forestland & 39 & 3 & 1 & 0 & 0 & 43 & $90.70 \%$ \\
\hline & Grassland & 1 & 57 & 2 & 1 & 1 & 62 & $91.94 \%$ \\
\hline Map & Cropland & 3 & 2 & 42 & 2 & 4 & 53 & $79.25 \%$ \\
\hline \multirow[t]{4}{*}{ Classes } & Wetland & 1 & 3 & 1 & 18 & 2 & 25 & $72.00 \%$ \\
\hline & Other land & 2 & 2 & 0 & 0 & 13 & 17 & $76.47 \%$ \\
\hline & Total & 46 & 67 & 46 & 21 & 20 & 200 & \\
\hline & Producer accuracy & $84.78 \%$ & $85.07 \%$ & $91.30 \%$ & $85.71 \%$ & $65.00 \%$ & & \\
\hline Overall accuracy & $84.50 \%$ & & & & & & & \\
\hline
\end{tabular}

(c)

\begin{tabular}{|c|c|c|c|c|c|c|c|c|}
\hline \multirow{2}{*}{\multicolumn{2}{|c|}{2005}} & \multicolumn{4}{|c|}{ Ground Classes } & \multirow[b]{2}{*}{ Other land } & \multirow[b]{2}{*}{ Total } & \multirow[b]{2}{*}{ User Accuracy } \\
\hline & & Forestland & Grassland & Cropland & Wetland & & & \\
\hline \multirow{7}{*}{ Map Classes } & Forestland & 49 & 3 & 0 & 1 & 3 & 56 & $87.50 \%$ \\
\hline & Grassland & 3 & 51 & 2 & 0 & 1 & 57 & $89.47 \%$ \\
\hline & Cropland & 1 & 2 & 55 & 3 & 4 & 65 & $84.61 \%$ \\
\hline & Wetland & 1 & 3 & 0 & 17 & 2 & 23 & $73.91 \%$ \\
\hline & Other land & 2 & 1 & 3 & 0 & 16 & 22 & $72.73 \%$ \\
\hline & Total & 56 & 60 & 60 & 21 & 26 & 223 & \\
\hline & Producer accuracy & $87.50 \%$ & $85.00 \%$ & $91.67 \%$ & $80.95 \%$ & $61.64 \%$ & & \\
\hline Overall accuracy & $84.30 \%$ & & & & & & & \\
\hline
\end{tabular}

(d)

\begin{tabular}{|c|c|c|c|c|c|c|c|c|}
\hline \multirow{2}{*}{\multicolumn{2}{|c|}{2015}} & \multicolumn{4}{|c|}{ Ground Classes } & \multirow[b]{2}{*}{ Other land } & \multirow[b]{2}{*}{ Total } & \multirow[b]{2}{*}{ User Accuracy } \\
\hline & & Forestland & Grassland & Cropland & Wetland & & & \\
\hline \multirow{7}{*}{ Map Classes } & Forestland & 57 & 2 & 1 & 0 & 1 & 61 & $93.44 \%$ \\
\hline & Grassland & 2 & 39 & 4 & 0 & 3 & 48 & $81.25 \%$ \\
\hline & Cropland & 3 & 4 & 62 & 3 & 2 & 74 & $83.78 \%$ \\
\hline & Wetland & 0 & 4 & 0 & 14 & 3 & 21 & $66.67 \%$ \\
\hline & Other land & 0 & 2 & 1 & 0 & 23 & 26 & $88.46 \%$ \\
\hline & Total & 62 & 51 & 68 & 17 & 32 & 230 & \\
\hline & Producer accuracy & $91.94 \%$ & $76.47 \%$ & $91.18 \%$ & $82.35 \%$ & $71.88 \%$ & & \\
\hline Overall accuracy & $84.78 \%$ & & & & & & & \\
\hline
\end{tabular}



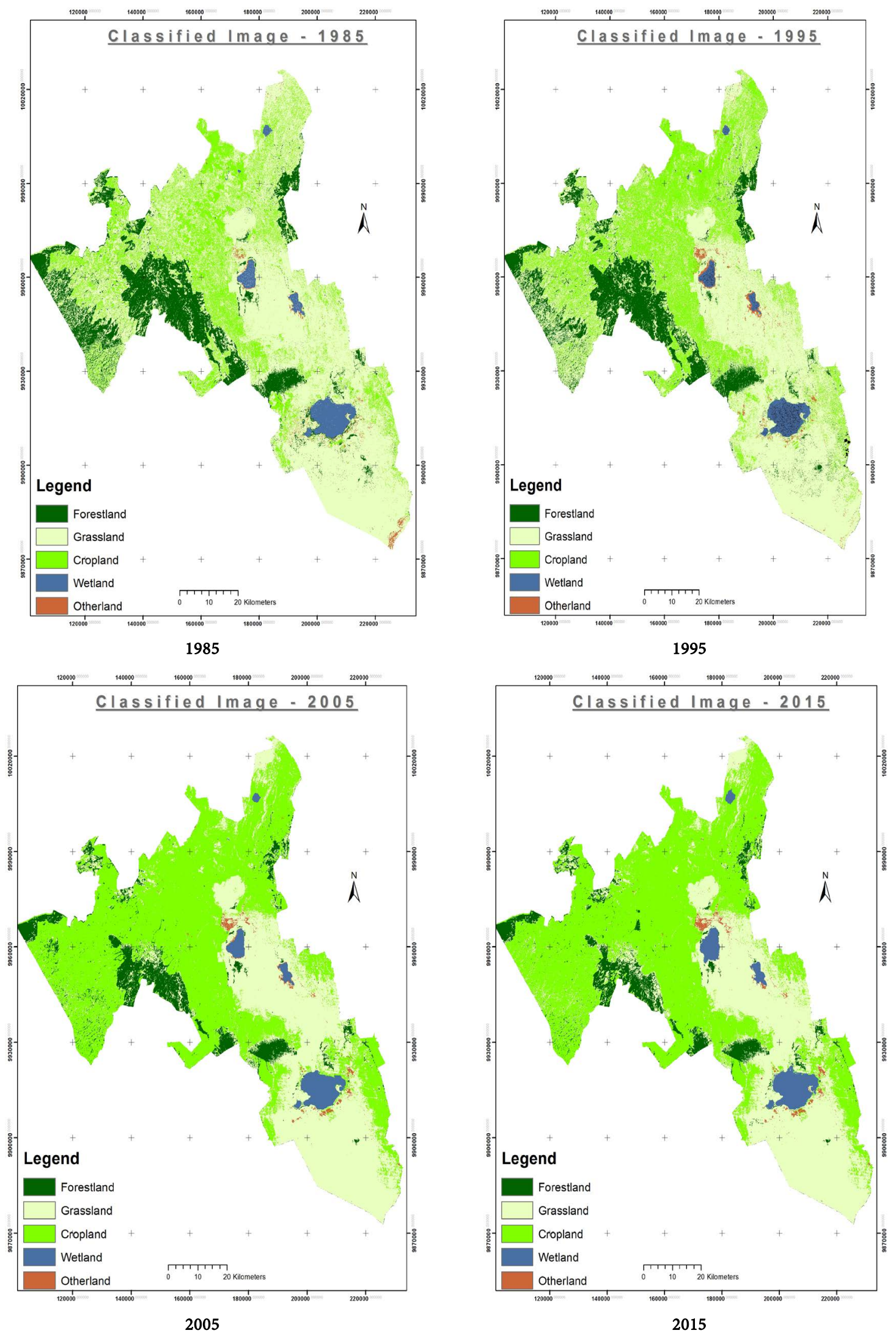

Source. Landsat 5 taken at March 1985, Landsat 5 taken at April 1985, Landsat 7 taken at April 2005, and Landsat 8 taken at March 2015.

Figure 3. Classified images for years 1985, 19952005 and 2015. 


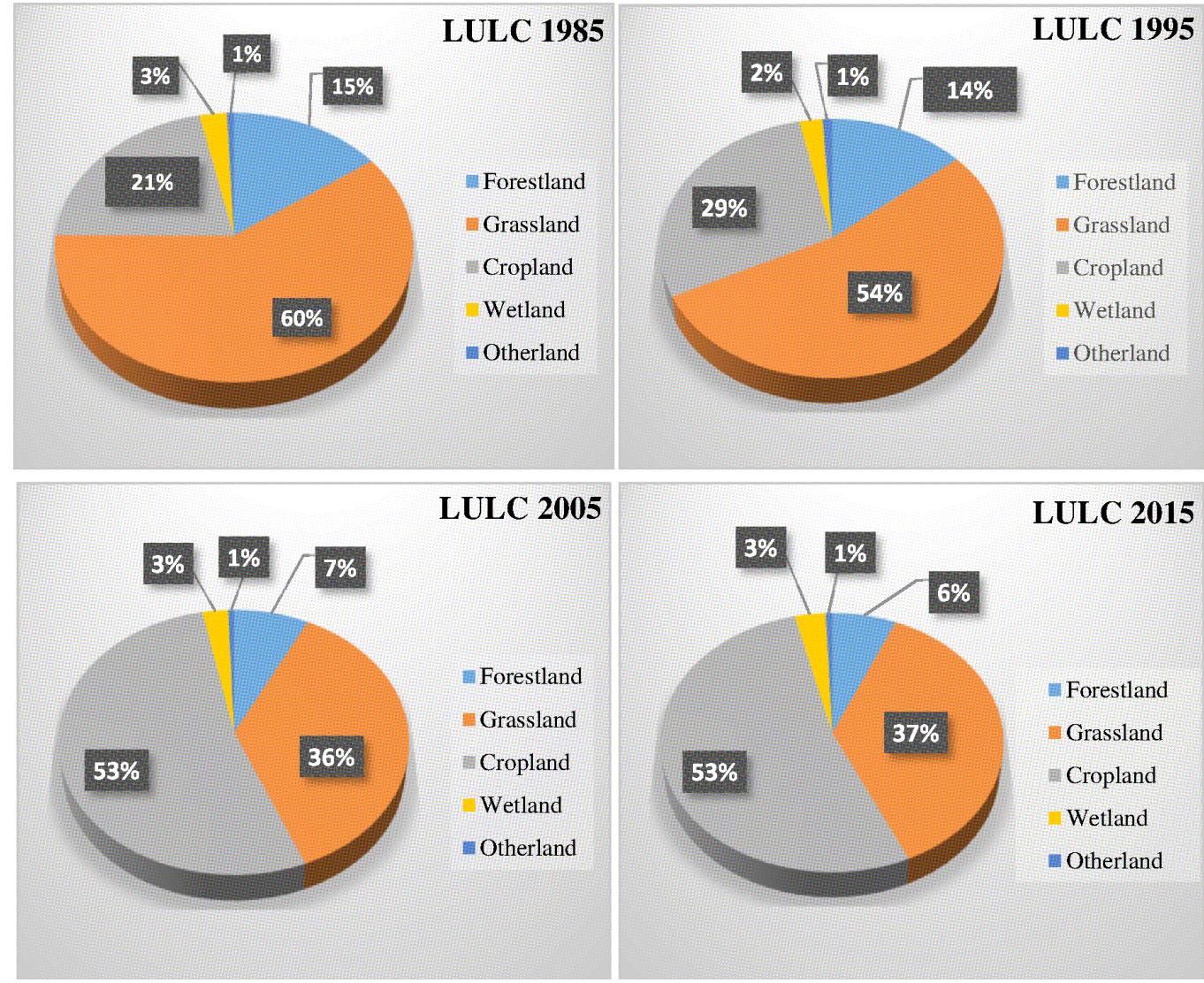

Figure 4. LULC classification in percentage.

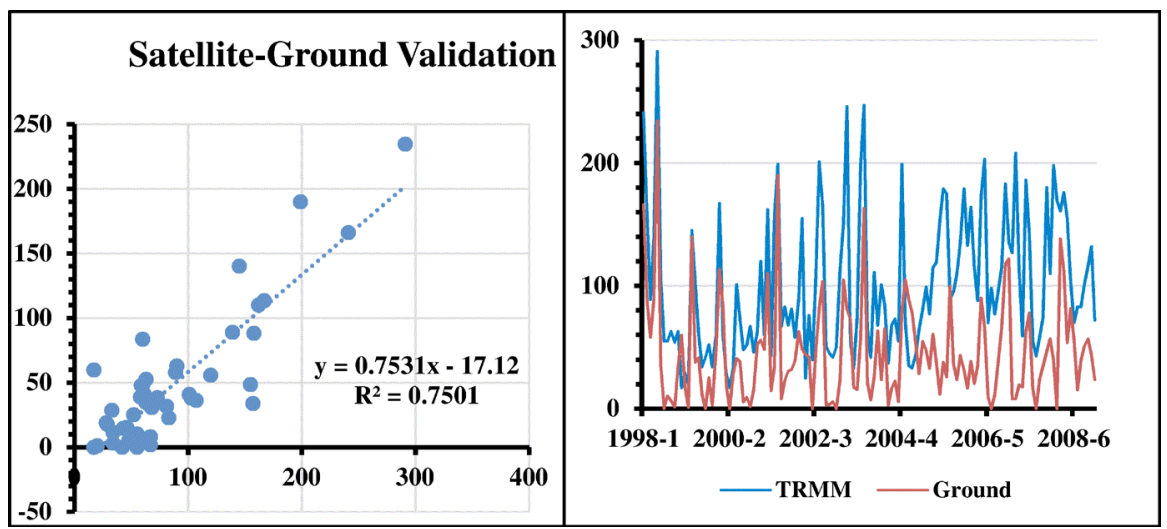

Figure 5. Correlation and validation for TRMM and ground data for Olkaria meteorological station.

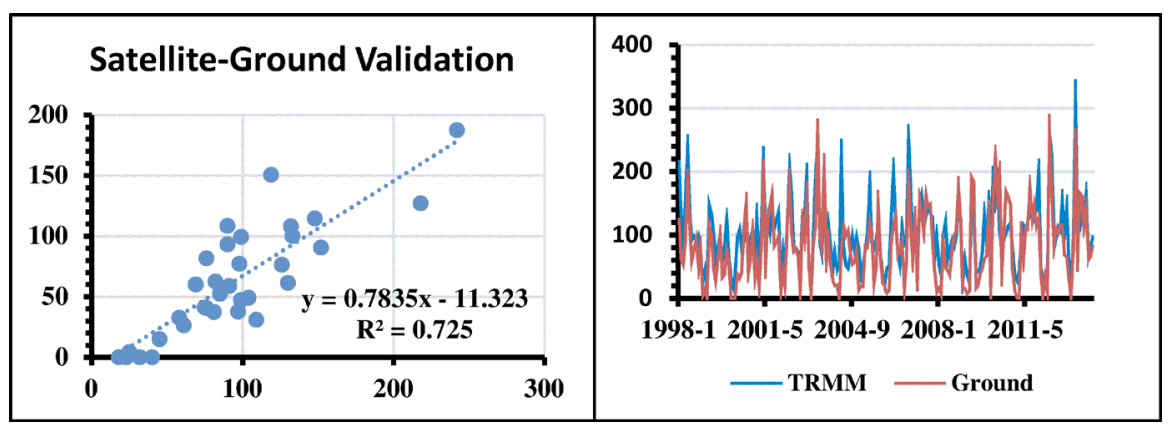

Figure 6. Correlation and validation for TRMM and ground data for Nakuru meteorological station (New). 


\subsection{Standard Precipitation Index (SPI) Application in Rainfall Modelling}

This procedure of rainfall modeling was done through the use of SPI timescales trend curves. From these various time scales curves, water scarce and dry years were identified. These were the season months which had the negative SPI values. Since SPI used normal distribution curve, the values are normalized [12]. Computation of the SPI involves fitting a gamma probability density function to a given frequency distribution of precipitation totals for a station. Figure 7 shows SPI curves for various timescales for Nakuru meteorological rainfall station and Figure 8 shows SPI curves for various timescales for Olkaria meteorological station. These SPI timescales curves graphically shows the SPI values; highest being the positive value and lowest is the negative value according to McKee et al., 1993 in Table 2. On the other hand, Kenya has three seasons according to Kenya meteorological department report [11]. These seasons are MAM, JJA, and OND, hence dry periods for these seasons were identified from the curves. Figures 9-11 show the SPI timescales curves for these three climatic seasons. Modeling the distribution of dry areas was done using IDW and categories

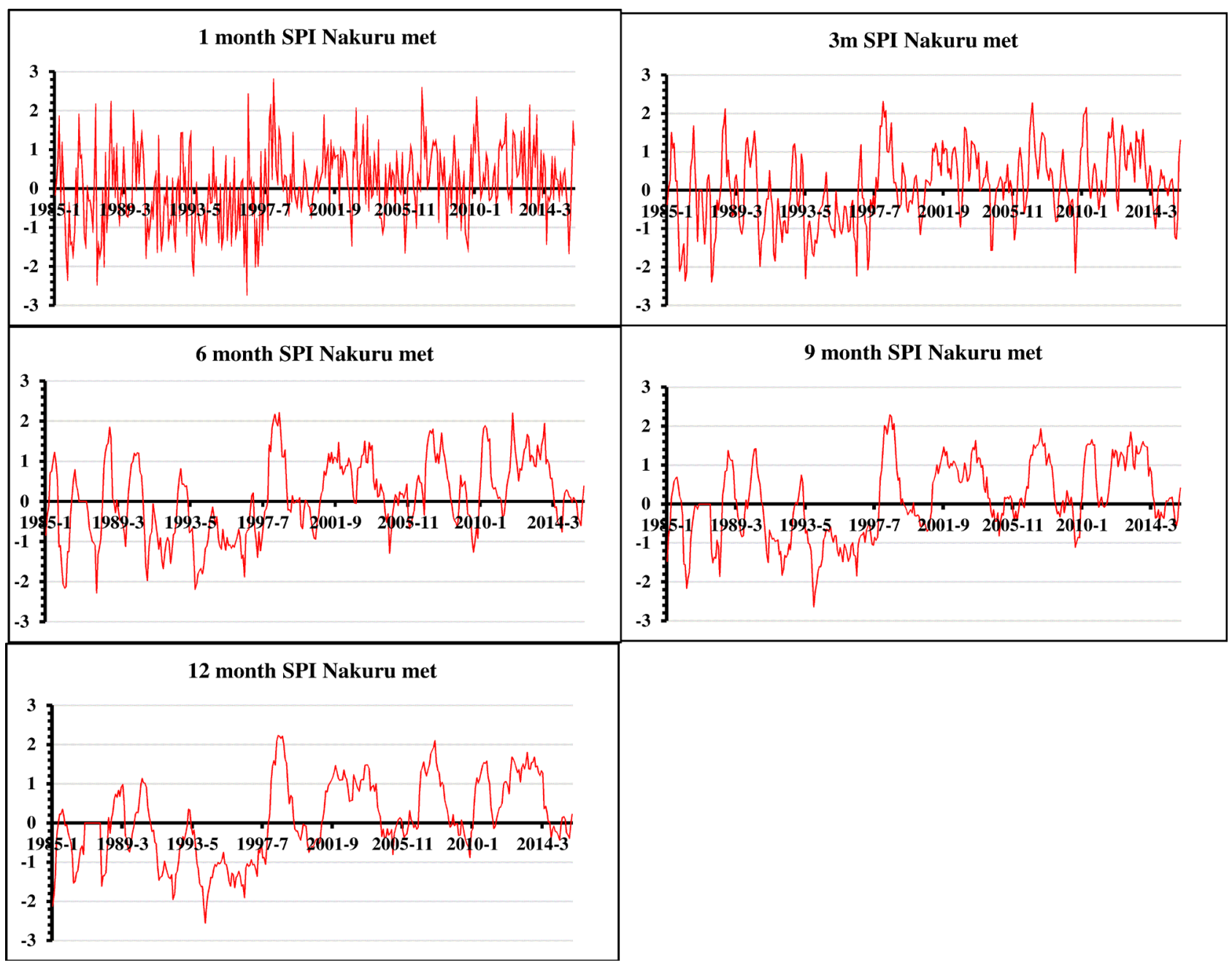

Figure 7. SPI time scales curves for Nakuru meteorological station (New). 


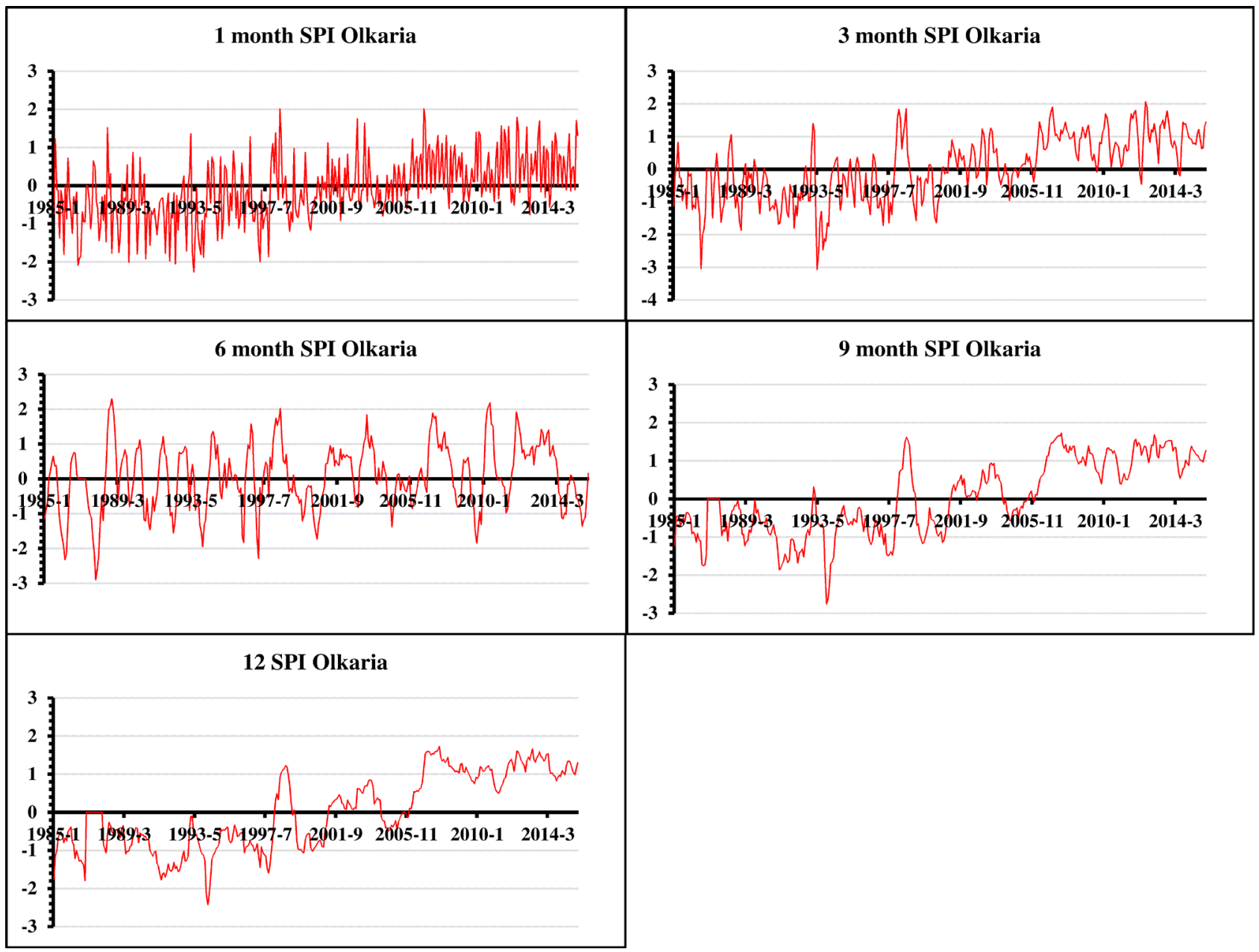

Figure 8. SPI time scales curves for Olkaria meteorological station.

or classes were according to McKee et al., 1993 [12].

Studies have shown that 3 Month SPI is what is being used to monitor agricultural drought and soil moisture [12]. Therefore the season curves are in Figures 9-11 respectively.

Figure 9 shows 3 month SPI for the month of October in the year 1987. October falls under OND season which is short rains reason as per the Kenya meteorological department report [11]. The year 1987 was identified as water scarce and drought year, and from Figure 9, all the 3 month SPI values were negative with Nessuit ground station in Molo Sub County having 3month SPI value of -3.08 .

The year 1993 was also identified as the water scarce and drought year. The month of May which falls under MAM season which is long rains period had contrary results because the 3 month SPI (3MSPI) values were low since the highest positive value was 0.25 at Karinget ground rainfall station in Kuresoi sub county and lowest negative value was -3.07 in Subukia ground rainfall station in Subukia Sub county. This is shown in Figure 10.

Figure 11 is for the year 2004 which was also identified as water scarce and drought year. All the 3 month SPI values were negative during the month of July 
which is JJA period categorized as dry season by Kenya meteorological department. Highest 3 month SPI negative value was -2.04 at Baraget ground rainfall station in Kuresoi sub county and the lowest 3 month SPI negative value was -0.61 Olkaria ground rainfall station in Naivasha Sub county.

From Figure 12, 3 month SPI for October 1987 showed that the highest SPI negative value is -3.08 , but it was during "short rains" season, that is, (OND season ) and most parts were categorized as very dry $(-1.5$ to -1.99$)$ as seen in Figure 12. Compared to crop yields graph, results are agreeing because the yield had decreased in this year. Upon analyzing the Figure 12 again, 3 month SPI of

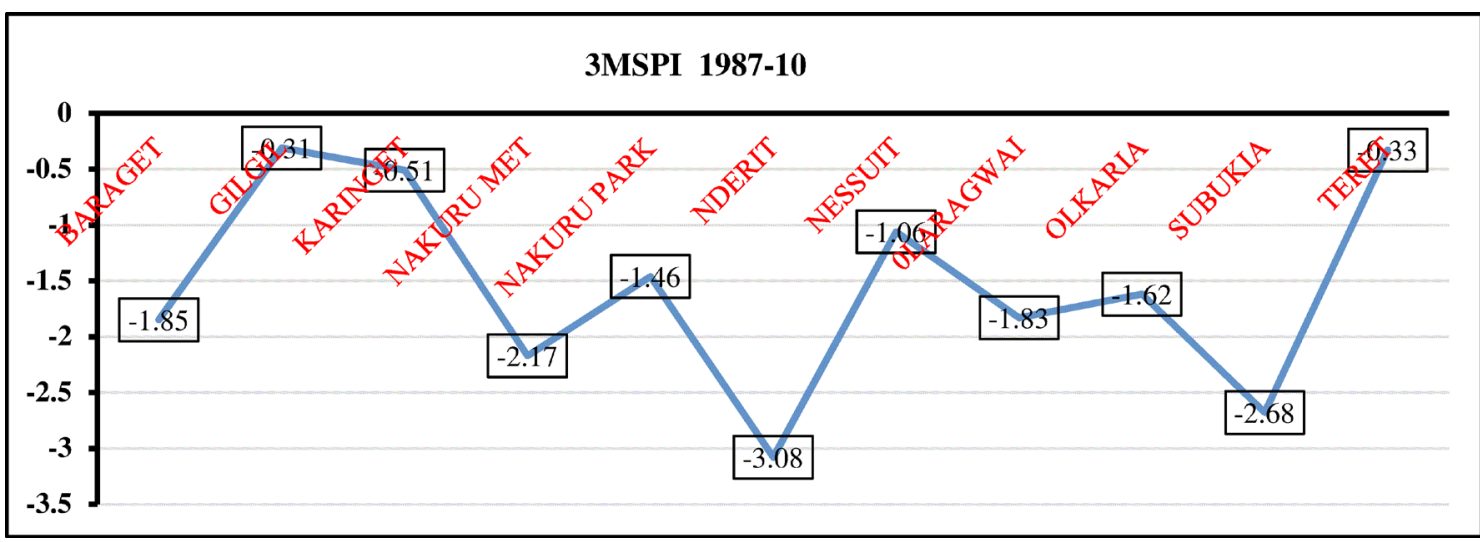

Figure 9. 3 MSPI for October 1987 (OND season).

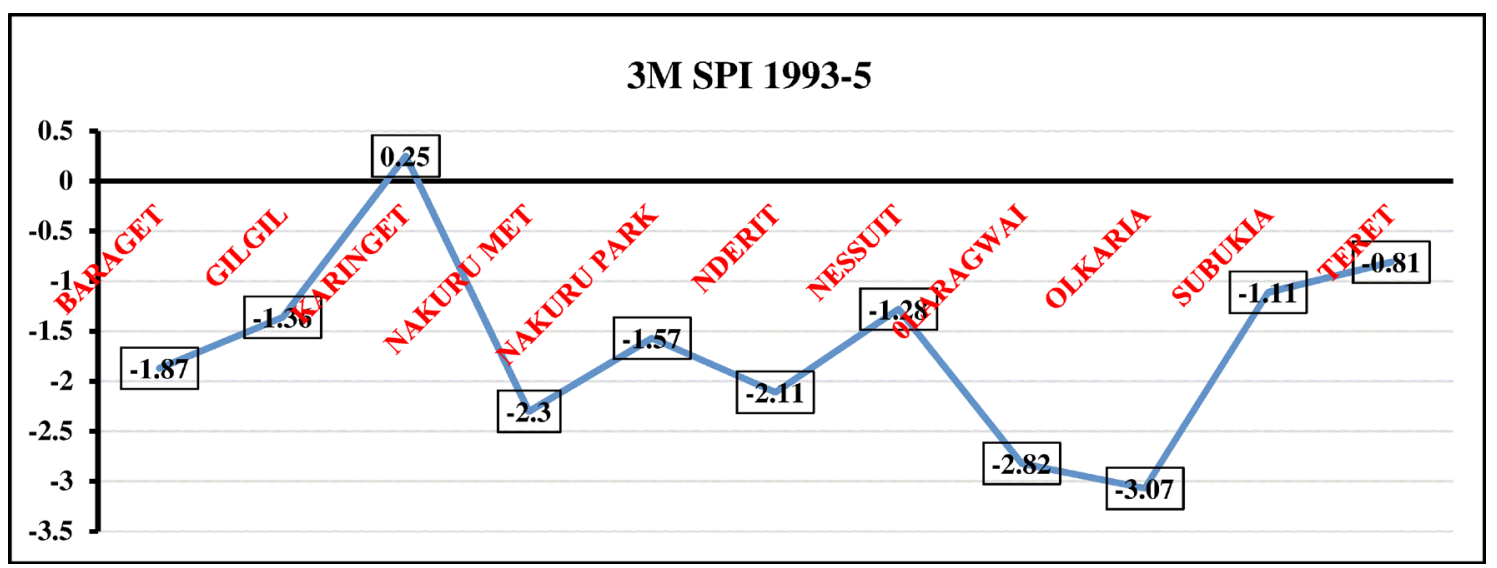

Figure 10. 3 MSPI for May 1993 (MAM season).

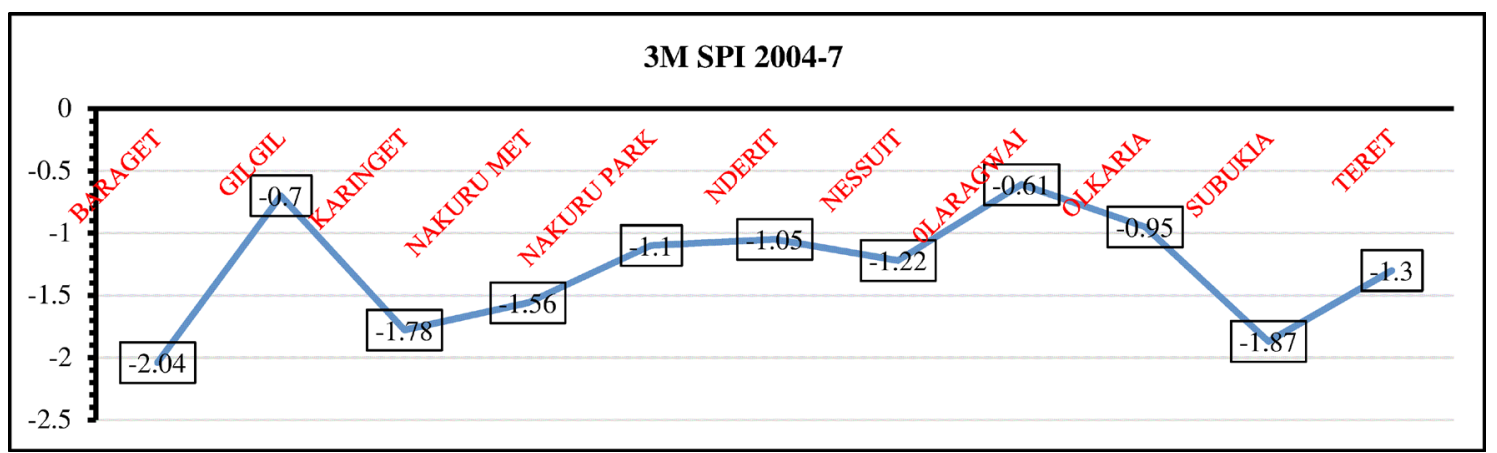

Figure 11. 3 MSPI for July 2004 (JJA season). 

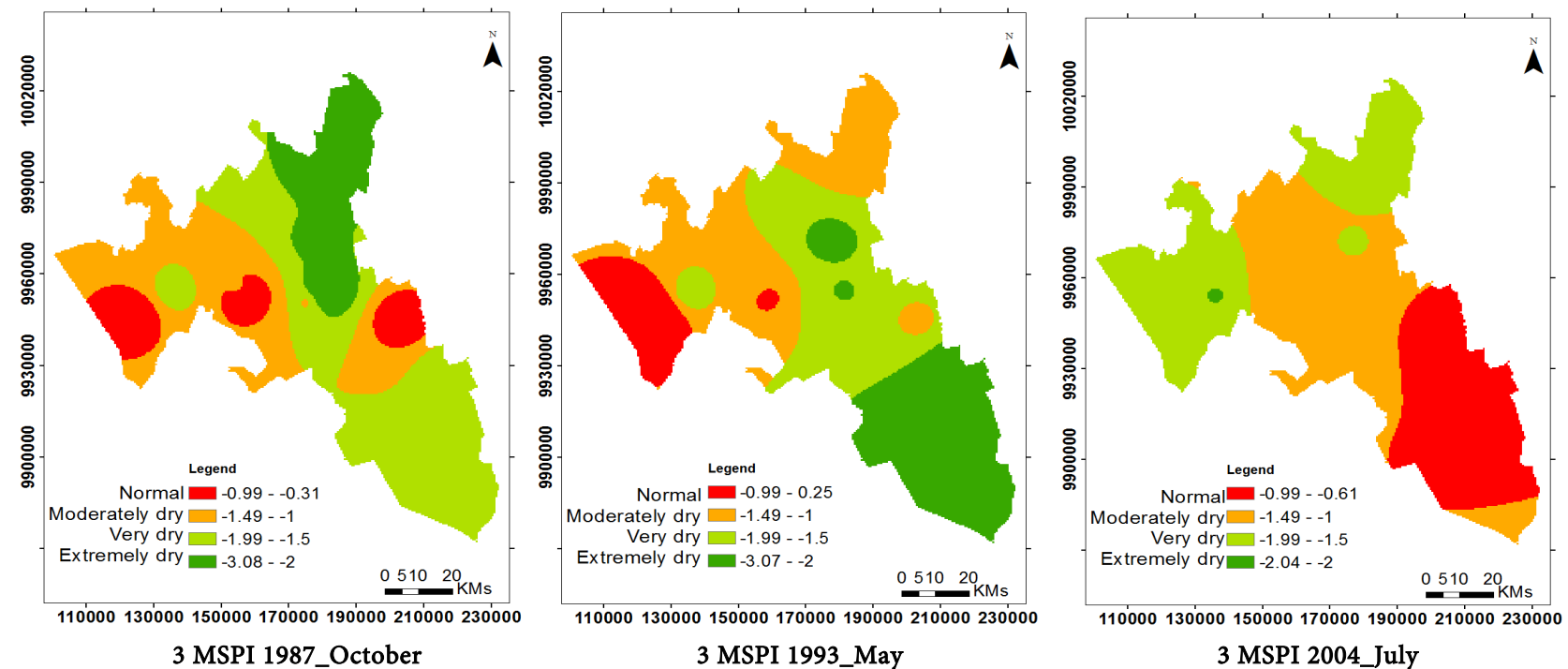

Figure 12. Modeling of identified drought years using 3 MSPI in MAM, JJA and OND season.

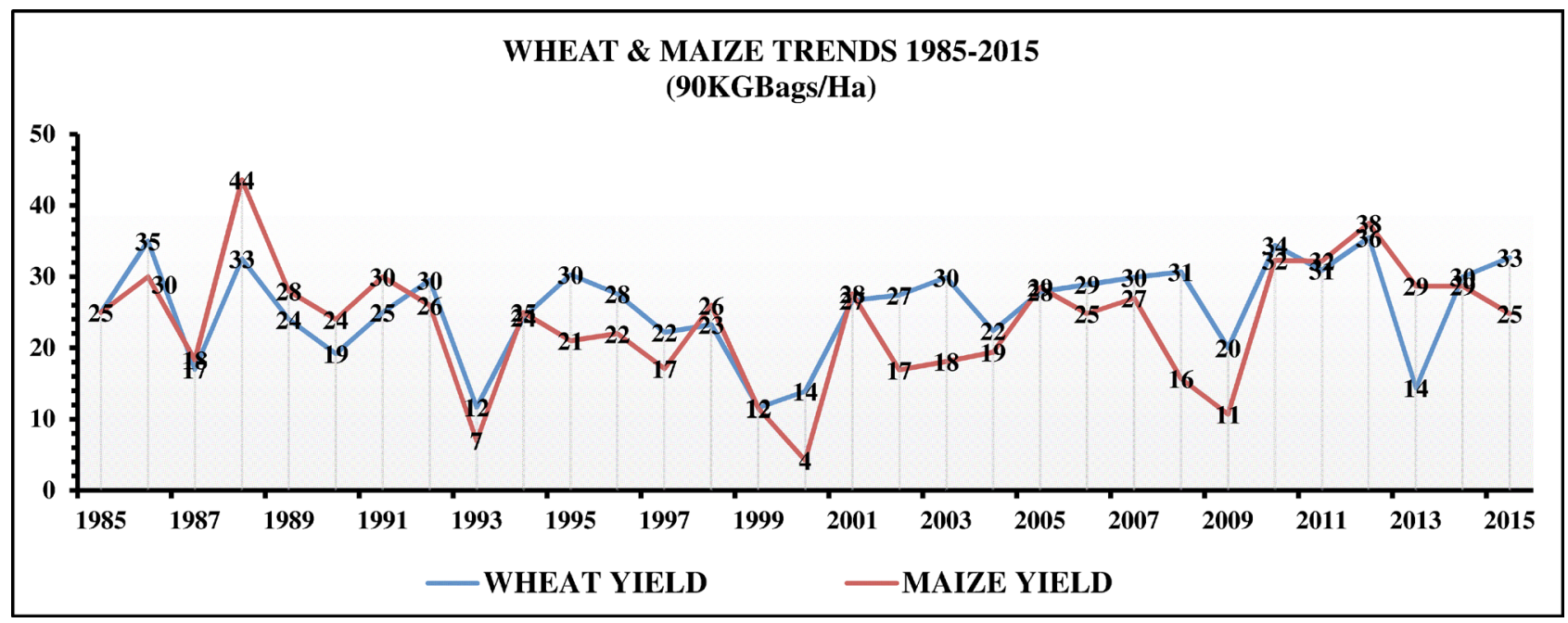

Figure 13. Wheat and Maize yields trend graph from the year 1985 to 2015.

the month of May 1993 showed that there was a balance in distribution of moderately dry, very dry and extremely dry. Areas with normal rainfall were very small. These results explain the fact that there was a lot of water scarcity and drought during this season. This is confirmed well in the crop yields graph in Figure 13 which showed a decrease in yields. Same case is displayed in the year 2004 where July which is under JJA season categorized as dry season by Kenya meteorological department. Here, the extremely dry area is very small while normal, moderate and very dry are balanced distribution.

\subsection{Crop Yield Data Processing and Trending of Crop Yield Graphs}

Long time series data for two dominant crops planted in Nakuru were organized in excel sheets and trend graphs drawn. The years covered was 1985 to 2015 and the two crops were maize and wheat. Results revealed that the trends for the two crops were in correlation and also it is evident that crop yields were low in the 
year 1987, year 1993 and the year 2004 as seen Figure 13.

\section{Conclusions}

\subsection{Conclusion on LULC Classification}

This research concludes that the size of land under crops doesn't necessarily determine the yields. Other factors like amount of rainfall and input may affect the yields. This is seen in respect to area occupied by crops in 1985, 1995, 2005, and 2015 in respect to the yields that was produced in those years.

\subsection{Conclusion on SPI Time Scales Rainfall Trends, Validation, Correlation and Water Scarcity and Drought Modelling}

From this research, it has been seen that TRMM satellite data can be used incase ground stations is not available. This is because their validation showed correlation as seen from the correlation coefficiency results. On the other hand, SPI has been realized as an effective index to monitor water and water scarcity, and therefore it can be used as early warning tools for decision makers and leaders to take precautionary measures against water scarcity and drought. This is because it can be modeled to show areas with drought severity.

\subsection{Conclusion on Crop Yields}

The research carried out has demonstrated that crop yield depends on the sufficiency of rainfall and not always the size of land ploughed. Decrease in water leads to decrease in yields and vice versa. On the other hand, rainfall amounts of MAM season have effect on the resultant crop yield of that particular year. It is because this is the period where we have long rains.

\section{Acknowledgements}

I wish to sincerely thank my supervisors Dr. Arthur W. Sichangi and Dr. Moses Murimi Ngigi for their technical guidance, my family for the financial support, and all those organizations who provided data for this research project. These organizations included: Regional Centre for Monitoring of Resources and Development (RCMRD), Ministry of Agriculture, Kenya Meteorological Department and the Nakuru County Government agriculture office.

\section{References}

[1] International Decade for Action "Water for Life" 2005-2015. http://www.un.org/waterforlifedecade/water_and_sustainable_development.shtml

[2] Watkins, K. (2006) Human Development Report, beyond Scarcity: Power, Poverty and the Global Water Crisis.

[3] Rebelo, M.L., Johnston, R. and Karimi, P.P. (2014) Determining the Dynamics of Agricultural Water Use: Cases from Asia and Africa.

[4] WIREs Water (2015) Hydrological Drought Explained. Wiley Periodicals, Inc., Hoboken.

[5] Stratfor Global Intelligence (2014) Water Scarcity-Examining Impacts around the 
World.

[6] Mishra, A.K. and Singh, V.P. (2010) A Review of Drought Concepts. Journal of Hydrology, 391, 202-216. https://doi.org/10.1016/j.jhydrol.2010.07.012

[7] Belal, A.B., El-Ramady, H.R., Mohamed, S.E. and Saleh, A. (2012) Drought Risk Assessment Using Remote Sensing and GIS Techniques. Arabian Journal of Geosciences, 7, 35-53.

[8] Jaeger, K.W., Plantinga, J.A., Chang, H., Dello, K., Grant, G., Hulse, D. and Wu, J. (2013) Toward a Formal Definition of Water Scarcity in Natural-Human Systems. Water Resources Research, 49, 4506-4517. https://doi.org/10.1002/wrcr.20249

[9] UN Water (2003) Water in a Changing World. The United Nations World Water Development Report 3.

[10] Mburu, S., Ogutu, C.A. and Mulwa, R. (2014) Analysis of Economic Efficiency and Farm Size: A Case Study of Wheat Farmers in Nakuru District, Kenya.

[11] Kenya Meteorological Department (2016) A Review of Rainfall during the "Long Rains" March to May (MAM) 2016 June July August (JJA) 2016 Seasons and the Outlook for the October November December (OND) 2016 Season.

[12] World Meteorological Organization (2012) Standardized Precipitation Index User Guide. Geneva.

Submit or recommend next manuscript to SCIRP and we will provide best service for you:

Accepting pre-submission inquiries through Email, Facebook, LinkedIn, Twitter, etc. A wide selection of journals (inclusive of 9 subjects, more than 200 journals)

Providing 24-hour high-quality service

User-friendly online submission system

Fair and swift peer-review system

Efficient typesetting and proofreading procedure

Display of the result of downloads and visits, as well as the number of cited articles

Maximum dissemination of your research work

Submit your manuscript at: http://papersubmission.scirp.org/

Or contact ars@scirp.org 